\title{
Research on Agricultural Innovation and Entrepreneurship Education System from the Perspective of Serving for Regional Industry_-Taking Rural Regional Development Specialty as an Example
}

\author{
Fangfang Zeng ${ }^{1, *}$ \\ ${ }^{1}$ Jinshan College of Fujian Agriculture and Forestry University, Fuzhou, Fujian 350002, China \\ *Corresponding author. Email: 13960757675@139.com
}

\begin{abstract}
\section{INTRODUCTION}

It is a major strategic deployment in China that firmly implementing the innovation driven development strategy. Higher agriculture and forestry education should play an important role in promoting the implementation of Rural Revitalization Strategy. It is the local universities' bounden duty to serve regional economy and society. The integration of industry and innovation is the inevitable trend of innovation driven development.
\end{abstract}

In order to promote the cultivation of agricultural innovation and entrepreneurship talents that can serve the regional industries, the study used the analytic hierarchy process as a tool and constructed an evaluation system for the cultivation of talents. The study selected 4 criteria levels and 19 index levels. The weight results of the evaluation system were determined according to the opinions of experts in relevant fields. The study suggested constructing the value recognition system, innovating the curriculum system of "youth's red dream building journey $+"$, building industry-innovation integration practice platform.

Keywords: Regional Industry; Service; Innovation and Entrepreneurship Education

\section{BACKGROUND}

\subsection{Macro background}

In 2015, the General Office of the State Council issued the implementation opinions on deepening the reform of innovation and entrepreneurship education in Colleges and universities. The document proposed to promote the close integration of higher education with science and technology, economy and society, and accelerate the training of innovative and entrepreneurial talents with large scale, innovative spirit and the courage to devote themselves to practice[1]. In 2017, the General Office of the State Council issued several opinions on deepening the integration of industry and education. The document further promoted the integrated development of education and industry into the overall institutional arrangement of national education reform and talent development. In 2019, the "Declaration of China's new agricultural science construction" and the Anji consensus was issued. It put forward the new era and new mission of implementing the Rural Revitalization Strategy requires the innovative development of higher agricultural and forestry education.

\subsection{Local background}

Fujian province implements the national education strategy. In 2015, the notice of Fujian Provincial People's Government on ten measures to vigorously promote mass entrepreneurship and innovation was issued. Another document ,the notice of Fujian Provincial Department of education on 16 measures to deepen the reform of innovation and entrepreneurship education in Colleges and universities, was issued in the same year. Fujian Province launched the first batch of pilot construction of innovation and entrepreneurship education reform. Its purpose is to promote the all-round integration and whole process coverage of innovation and entrepreneurship education and professional education, and strive to enhance students' innovative spirit, entrepreneurial awareness and innovative and entrepreneurial ability[2].In 2019, Fujian Provincial Department of Education launched the construction of the first batch of provincial industry innovation integration education practice demonstration bases. Integration of industry and innovation has become an upgraded version of integration of industry and education for Fujian to build a Innovation and Entrepreneurship education system[3].

\subsection{Micro background}

China's economic development has entered a new normal, and the demand for high-quality applied talents is 
becoming more and more urgent with the transformation and upgrading of industry. This trend is consistent with the training goal of Application-oriented Colleges and universities to cultivate high-quality talents who can meet the needs of regional industrial development[4]. The cultivation of applied talents has become an important bridge between colleges and universities and the coordinated development of regional industries. On one hand, while serving the development of regional industries, application-oriented universities not only help to clarify their development orientation and highlight their self-worth, but also obtain a large number of school running resources and expand the space for their own survival and development. On the other hand, regional industrial development also objectively requires application-oriented universities to cultivate talents in line with industrial needs according to the local social and economic development. In 2020, Rural Regional Development Specialty of Jinshan College of Fujian Agriculture and Forestry University was selected as the first batch of first-class undergraduate specialty construction sites in Fujian Province. The general requirement of the specialty is to establish morality and cultivate people as the foundation, to strengthen agriculture and prosper agriculture as its own responsibility, and to serve rural development as the orientation. It is committed to cultivating applied rural construction talents who knows agriculture, rural areas and farmers, understands economy, be good at management and planning[5].

\section{CONSTRUCTION OF EVALUATION SYSTEM}

\subsection{Constructing evaluation index system}

The evaluation of agricultural Innovation and Entrepreneurship talent training oriented to regional industry should include knowledge level[6], ability level, quality level and talent training effect.

Specifically, this study selects four criteria levels: knowledge level (B1), comprehensive ability (B2), emotional quality (B3) and achievements (B4), which can be subdivided into general knowledge $(\mathrm{C} 1)$, management knowledge (C2), agricultural knowledge (C3), planning knowledge (C4), innovation and entrepreneurship creation knowledge (C5), communication ability (C6), information acquisition ability (C7), application ability (C8), resource development ability (C9), team assistance ability (C10), project promotion ability $(\mathrm{C} 11)$, awareness of innovation, entrepreneurship and creation policy (C12), awareness of Rural Revitalization Strategy (C13), feelings for agriculture, rural areas and farmers (C14), experience of innovation, entrepreneurship and creation (C15), participation in innovation, entrepreneurship and creation activities (C16), competition awards (C17), the number of agricultural enterprises (C18), and the industrial situation in the service area (C19).

The construction of the evaluation index system and the meaning of each index are shown in Table 1.

Table 1. Evaluation system of agricultural innovation and entrepreneurship talent training oriented by regional industry

\begin{tabular}{|c|c|c|}
\hline Target Layer A & Element Layer B & Index Layer C \\
\hline \multirow{19}{*}{$\begin{array}{l}\text { Agricultural Innovation and Entrepreneurship talent training } \\
\text { oriented by regional industry } \\
\text { (A) }\end{array}$} & \multirow{5}{*}{$\begin{array}{l}\text { Knowledge level } \\
\text { (b1) }\end{array}$} & General knowledge (C1) \\
\hline & & Management knowledge (C2) \\
\hline & & Agricultural knowledge (C3) \\
\hline & & Planning knowledge (C4) \\
\hline & & $\begin{array}{c}\text { Innovation and entrepreneurship creation } \\
\text { knowledge (C5) }\end{array}$ \\
\hline & \multirow{6}{*}{$\begin{array}{l}\text { Comprehensive } \\
\text { ability } \\
\text { (b2) }\end{array}$} & Communication ability (C6) \\
\hline & & Information acquisition ability (C7) \\
\hline & & Application ability (C8) \\
\hline & & Resource development ability (C9) \\
\hline & & Team assistance ability (C10) \\
\hline & & Project promotion ability $(\mathrm{C} 11)$ \\
\hline & \multirow{3}{*}{$\begin{array}{l}\text { Emotional quality } \\
\text { (b3) }\end{array}$} & $\begin{array}{c}\text { Awareness of innovation, entrepreneurship and } \\
\text { creation policy (C12) }\end{array}$ \\
\hline & & $\begin{array}{c}\text { Awareness of Rural Revitalization Strategy } \\
\text { (C13) }\end{array}$ \\
\hline & & $\begin{array}{l}\text { Feelings for agriculture, rural areas and farmers } \\
(\mathrm{C} 14)\end{array}$ \\
\hline & \multirow{5}{*}{ Achievements (B4) } & $\begin{array}{c}\text { Experience of innovation, entrepreneurship and } \\
\text { creation (C15) }\end{array}$ \\
\hline & & $\begin{array}{c}\text { Participation in innovation, entrepreneurship } \\
\text { and creation activities (C16) }\end{array}$ \\
\hline & & Competition awards (C17) \\
\hline & & The number of agricultural enterprises (C18) \\
\hline & & The industrial situation in the service area (C19) \\
\hline
\end{tabular}




\subsection{Constructing judgment matrix}

In order to give better play to the decision-making advantages of experts in complex evaluation system, this study uses analytic hierarchy process, which is commonly used in weighting method, to determine the weight.We invite six experts from national leisure agriculture and rural tourism, China Agricultural University, Fujian agriculture and rural department, Hebei Agricultural University, Fujian agriculture and Forestry University and other government functional departments, scientific research institutes, universities and academic groups. This study adopts the scale of 1-9, compares the indicators and carries out multiple rounds of consultation. The judgment matrix of criterion layer B relative to target layer a is shown in Table 2 , and the judgment matrix of index layer $\mathrm{C}$ relative to criterion layer B is shown in tables 3, 4, 5 and 6 .

Table 2. Judgment matrix of a - (B1 B4)

$\mathrm{CR}=0.0952$; weight to $\mathrm{A}=1.0000 ; \lambda \max =4.2542$

\begin{tabular}{|c|c|c|c|c|c|}
\hline A & B1 & B2 & B3 & B4 & weight \\
\hline B1 & 1.0000 & 0.3333 & 0.3333 & 0.1667 & 0.0706 \\
\hline B2 & 3.0000 & 1.0000 & 5.0000 & 0.5000 & 0.3265 \\
\hline B3 & 3.0000 & 0.2000 & 1.0000 & 0.2500 & 0.1221 \\
\hline B4 & 6.0000 & 2.0000 & 4.0000 & 1.0000 & 0.4808 \\
\hline
\end{tabular}

Table 3. Judgment matrix of B1-(C1 C5)

$\mathrm{CR}=0.0694 ;$ weight to $\mathrm{A}=0.0706 ; \lambda \max =5.3107$

\begin{tabular}{|c|c|c|c|c|c|c|}
\hline B1 & C1 & C2 & C3 & C4 & C5 & weight \\
\hline C1 & 1.0000 & 0.2500 & 0.1667 & 0.1429 & 0.1429 & 0.0371 \\
\hline C2 & 4.0000 & 1.0000 & 3.0000 & 0.5000 & 0.3333 & 0.1835 \\
\hline C3 & 6.0000 & 0.3333 & 1.0000 & 0.2500 & 0.5000 & 0.1227 \\
\hline C4 & 7.0000 & 2.0000 & 4.0000 & 1.0000 & 1.0000 & 0.3341 \\
\hline C5 & 7.0000 & 3.0000 & 2.0000 & 1.0000 & 1.0000 & 0.3225 \\
\hline
\end{tabular}

Table 4. .Judgment matrix of B2-(C6 C11)

$\mathrm{CR}=0.0404$; weight to $\mathrm{A}=0.3265 ; \lambda \max =6.2548$

\begin{tabular}{|c|c|c|c|c|c|c|c|}
\hline B2 & C6 & C7 & C8 & C9 & C10 & C11 & weight \\
\hline C6 & 1.0000 & 0.3333 & 0.3333 & 0.2500 & 1.0000 & 0.5000 & 0.0812 \\
\hline C7 & 3.0000 & 1.0000 & 0.5000 & 0.5000 & 1.0000 & 0.5000 & 0.1361 \\
\hline C8 & 3.0000 & 2.0000 & 1.0000 & 1.0000 & 1.0000 & 1.0000 & 0.2076 \\
\hline C9 & 4.0000 & 2.0000 & 1.0000 & 1.0000 & 1.0000 & 1.0000 & 0.2206 \\
\hline C10 & 1.0000 & 1.0000 & 1.0000 & 1.0000 & 1.0000 & 1.0000 & 0.1599 \\
\hline C11 & 2.0000 & 2.0000 & 1.0000 & 1.0000 & 1.0000 & 1.0000 & 0.1946 \\
\hline
\end{tabular}

Table 5. Judgment matrix of B3-(C12 C14)

$\mathrm{CR}=0.0176$; weight to $\mathrm{A}=0.1221 ; \lambda \max =3.0183$

\begin{tabular}{|c|c|c|c|c|}
\hline B3 & C12 & C13 & C14 & weight \\
\hline C12 & 1.0000 & 0.3333 & 0.5000 & 0.1692 \\
\hline C13 & 3.0000 & 1.0000 & 1.0000 & 0.4434 \\
\hline C14 & 2.0000 & 1.0000 & 1.0000 & 0.3874 \\
\hline
\end{tabular}

Table 6. Judgment matrix of B4-(C15 C19)

$\mathrm{CR}=0.0425$; weight to $\mathrm{A}=0.4808 ; \lambda \max =5.1904$

\begin{tabular}{|c|c|c|c|c|c|c|}
\hline B4 & C15 & C16 & C17 & C18 & C19 & weight \\
\hline C15 & 1.0000 & 0.3333 & 0.1429 & 0.2500 & 0.1250 & 0.0374 \\
\hline C16 & 3.0000 & 1.0000 & 0.2500 & 0.5000 & 0.1250 & 0.0729 \\
\hline C17 & 7.0000 & 4.0000 & 1.0000 & 3.0000 & 0.3333 & 0.2650 \\
\hline C18 & 4.0000 & 2.0000 & 0.3333 & 1.0000 & 0.3333 & 0.1308 \\
\hline C19 & 8.0000 & 8.0000 & 3.0000 & 3.0000 & 1.0000 & 0.4939 \\
\hline
\end{tabular}

\subsection{To determine the weight of the index}

In Table 3, the consistency ratio $\mathrm{CR}$ of the judgment matrix of $\mathrm{B} 1-(\mathrm{C} 1 \sim \mathrm{C} 5)$ is 0.0694 ; In Table 4, the consistency ratio CR of judgment matrix of B2 - (C6 C11) is 0.0404; In Table 5, the consistency ratio $\mathrm{CR}$ of judgment matrix of B3 - $(\mathrm{C} 12 \sim \mathrm{C} 14)$ is 0.0176; In Table 6, the consistency ratio $\mathrm{CR}$ of the judgment matrix of $\mathrm{B} 4-(\mathrm{C} 15 \sim \mathrm{C} 19)$ is 0.0425 , which is less than 0.01 , which is regarded as passing the one-time inspection. The consistency index CR of hierarchical total ranking is $0.0952<0.10$. It is considered that the calculation results of the model have satisfactory consistency and can accept the analysis results of total ranking of index weight of agricultural three innovation talent training evaluation system oriented by regional industry, as shown in Table 7.

Table 7. Evaluation system Weight of agricultural Innovation and Entrepreneurship talent training oriented by regional industry

\begin{tabular}{|c|c|c|c|c|}
\hline Target Layer A & Element Layer B & $\begin{array}{c}\text { Criterion } \\
\text { weight }\end{array}$ & Index Layer C & $\begin{array}{c}\text { Comprehensive } \\
\text { weight }\end{array}$ \\
\hline \multirow{8}{*}{$\begin{array}{l}\text { Agricultural Innovation and } \\
\text { Entrepreneurship talent training oriented } \\
\text { by regional industry(A) }\end{array}$} & \multirow{5}{*}{$\begin{array}{l}\text { Knowledge level } \\
\text { (B1) }\end{array}$} & \multirow{5}{*}{0.0706} & General knowledge (C1) & 0.0026 \\
\hline & & & Management knowledge (C2) & 0.0130 \\
\hline & & & Agricultural knowledge (C3) & 0.0087 \\
\hline & & & Planning knowledge (C4) & 0.0236 \\
\hline & & & $\begin{array}{l}\text { Innovation and entrepreneurship } \\
\text { creation knowledge (C5) }\end{array}$ & 0.0228 \\
\hline & \multirow{3}{*}{$\begin{array}{l}\text { Comprehensive } \\
\text { ability } \\
\text { (B2) }\end{array}$} & \multirow{3}{*}{0.3265} & Communication ability (C6) & 0.0265 \\
\hline & & & $\begin{array}{l}\text { Information acquisition ability } \\
\text { (C7) }\end{array}$ & 0.0444 \\
\hline & & & Application ability (C8) & 0.0678 \\
\hline
\end{tabular}




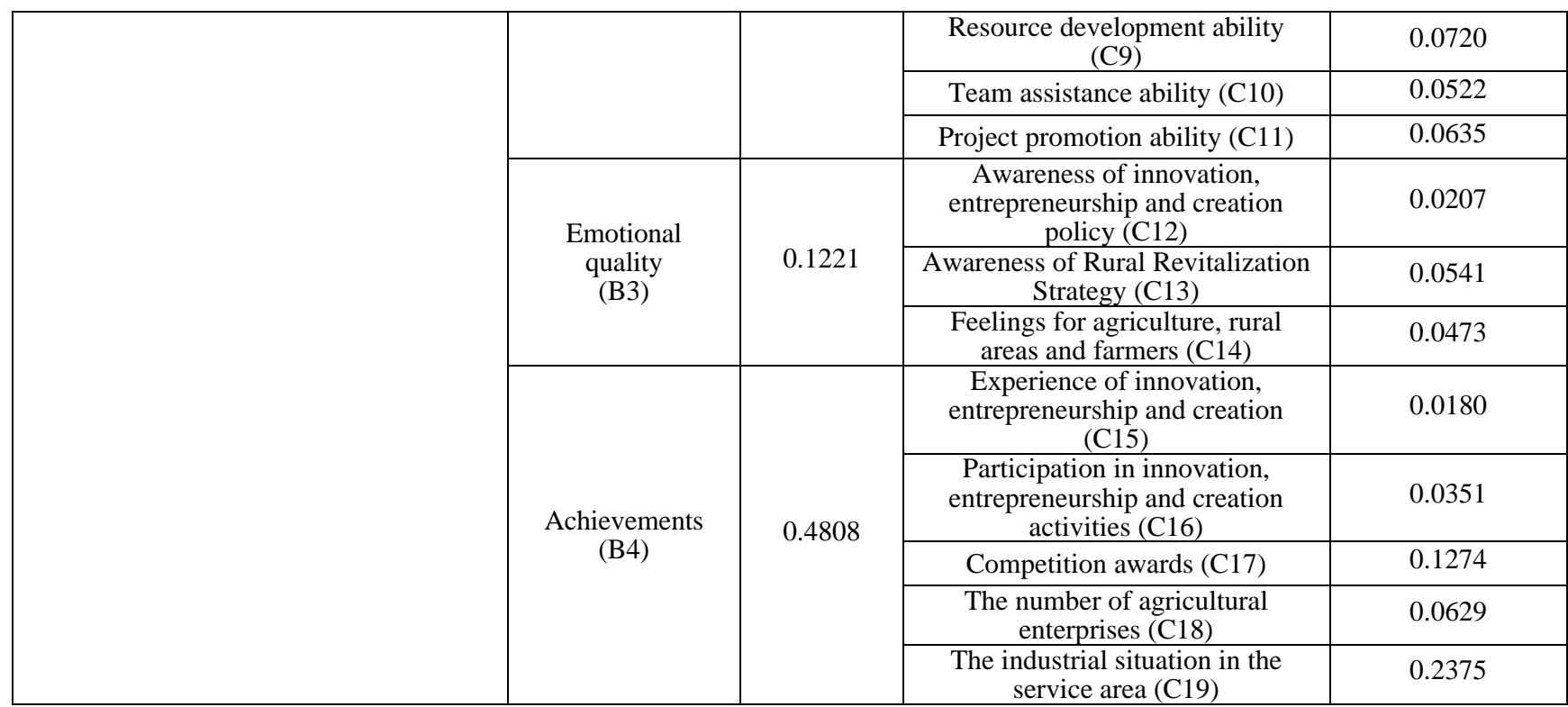

create resources, use theoretical knowledge to solve practical problems and expand the influence of projects.

\section{EVALUATION RESULTS AND ANALYSIS}

\subsection{The weight ranking results of criterion layer $B$ relative to target layer $A$.}

The Innovation and Entrepreneurship achievements B4 $(0.4808)>$ comprehensive ability B2 $(0.3265)>$ emotional quality B3 (0.1221) > knowledge level B1 (0.0706). The ranking results are consistent with the results oriented talent training evaluation system, focusing on the examination of practical ability and strengthening emotional quality education on the basis of knowledge learning.

\subsection{The weight ranking results of index layer $C$ relative to target layer $A$.}

The top five are the service area industry situation C19 (0.2375), the competition award C17 (0.1274) above the provincial and ministerial level, the resource development ability C9 (0.0720), the application ability C8 (0.0678), and the project promotion ability $\mathrm{C} 11(0.0635)$. This shows that during the construction of the results oriented talent training evaluation system, we should pay attention to the driving role of the examination results in driving the development of regional industries and absorbing the employment of regional labor force, and actively encourage students to participate in various innovation and entrepreneurship competitions at all levels, so as to promote teaching and learning through competition. Through the reform of the curriculum system, we should improve students' ability to discover, excavate and integrate agricultural innovation and entrepreneurship,

\section{COUNTERMEASURES}

\subsection{Constructing the value recognition system}

First, strengthening the foundation of theoretical identity, increase the value guidance of innovation, entrepreneurship and creation policies and learning from farmers and loving farmers on the basis of professional course learning, and imperceptibly enable college students to consolidate the value-oriented theoretical identity of three innovation education and service areas in the process of professional course learning. Second, activating the motivation of emotional identity. On the basis of theoretical recognition, by introducing the innovation and entrepreneurship creation story of positive energy service regional industry into the classroom, it can arouse students' emotional resonance, so as to promote students' recognition of the three innovation education values of service regional industry. Third, promoting behavior identity. By strengthening social practice in summer vacation, going to the countryside, curriculum practice and other practical activities, the classroom is extended from the school to the practice base, integrated into the era background of Rural Revitalization Strategy, and carried out in the agricultural and rural environment with real projects as the carrier, so as to improve students' agricultural entrepreneurship and creation practice ability. 


\subsection{Innovating the curriculum system of "youth's red dream building journey +"}

First, integrating into the social practice of first-class curriculum construction, guided by the concept of "integration of industry, education, competition and education and serving rural revitalization", guide the student team to deeply understand the national conditions and people, and use innovative thinking and entrepreneurial ability to serve the society. Second, integrating into traditional professional courses, organically integrate professional education and innovation, entrepreneurship and creation education, reflect the organic integration of Ideological and political education and innovation, entrepreneurship and creation education, and form a characteristic course of integration of new agricultural science, specialty and creation. Third, integrating innovation, entrepreneurship, creation and general knowledge courses, cultivate infected students with innovative thinking of new agricultural science, learn something and use it, actively participate in the team of innovative talents serving agriculture, rural areas and farmers, and become a participant in the construction and development of modern agriculture.

\subsection{Building an industry innovation integration practice platform}

Constructing the integration channel with agricultural professional characteristics is the key to break through the bottleneck of implementation effect. By jointly building an industry innovation integration practical teaching platform with enterprises, taking the specific reality of farmers, agriculture and rural areas in the practice base as teaching materials, highlight the central position of students' learning, and organically integrate practical teaching with the development of agricultural and rural industries under the guidance of project results, so as to form "taking the pain point of industry as the starting point of agricultural innovation and entrepreneurship, The practical teaching logic of "integration of industry and education" with "serving regional industrial development as the practice foothold", so as to adhere to the synchronous promotion of teaching practice and social service, and realize the integration and progress of talent training and promoting the development of regional agricultural industry.

\section{CONCLUSION}

First, cultivating agricultural Innovation and Entrepreneurship talents meets the internal requirements of national implementation of innovation driven development strategy and Rural Revitalization Strategy. Second, we should pay attention to the results oriented talent training evaluation system, focus on the examination of practical ability and strengthen emotional quality education on the basis of knowledge learning. Third, in order to achieve talent training objectives, we should follow the following path such as constructing the value recognition system, innovating the curriculum system of "youth's red dream building journey +", building industry-innovation integration practice platform.

\section{ACKNOWLEDGMENT}

Thanks for the fund from Higher education teaching reform project of Jinshan College of Fujian agriculture and Forestry University" Research on the cultivation of innovative and entrepreneurial talents in agriculture and forestry based on the integration of industry and innovation".

\section{REFERENCES}

[1]Xuemei SHI., "Research on the construction of evaluation system of innovative and entrepreneurial talents in Colleges of Humanities and Social Sciences," Science and technology horizon, pp.129-130, June 2020. (In Chinese)

[2]Qingmin ZHANG. Link and Cooperation: Internal Logic of the Organic Connection of "Four Chains" in the Integration of Industry and Education Journal of National Institute of Education Administration.pp.48-56, April 2021. (In Chinese)

[3]Xing CAI. Research on the education mechanism of government, enterprise and school based on the integration of industry and education in private colleges and Universities. Vocational \& Technical Education Forum. pp.139-143, Mar 2021. (In Chinese)

[4]Shu-mei GUO. Research on Cooperative Education of Applied Agriculture-related Specialties under the Background of Industry-education Integration. Journal of Anhui Agricultural Sciences..pp275-276. Mar 2021. (In Chinese)

[5]Fangfang ZENG. "Study on the Applied Talents Training Mode of "Four-in-One" for Rural Regional Development Specialty-Taking Jinshan College of Fujian Agricultural and Forestry University as an Example". Journal of Beijing City University, pp.71-74, Aug 2020.(In Chinese)

[6]Jiajing ZHANG, "Research on the cultivation path of innovative and entrepreneurial values of Agricultural College Students,” Modern trade industry, pp.79-80, 